\title{
Aspectos da natalidade no povoamento do Centro-Oeste Paulista, Século XIX
}

\author{
Aspects of the birthrate in Midwestern "Paulista" Settlement, 19th Century
}

Edson FERNANDES ${ }^{\bullet}$

Resumo: Este trabalho aborda aspectos da natalidade num território de fronteira. A região oeste da Província de São Paulo, em sua área delimitada pelos rios Tietê e Paranapanema, foi a fronteira do povoamento durante boa parte do século XIX. A análise dos registros paroquiais e cartoriais de Lençóes permitiu traçar aspectos da família nessa região. Por meio desse estudo, vemos que a ilegitimidade era baixa, menor do que em outras áreas que serviram de parâmetro, contrariando o que poderia se esperar para uma área de fronteira. Os batismos ocorriam em maior quantidade nos meses finais do ano (novembro e dezembro), seguidos pelo mês inicial, janeiro. Não havia acentuadas variações sazonais com relação aos batismos, embora os meses de outubro, fevereiro e março fossem aqueles de menor ocorrência. Enquanto o domingo era o dia preferido pelos pais para esta cerimônia, concentrando aproximadamente um terço delas, sexta-feira era um dia a ser evitado. Palavras-chave: Fronteira; Natalidade; Legitimidade.

Abstract: This work approaches the aspects of birth rate in a frontier territory. The west region of São Paulo Province, in its area delimitated by the Tietê and the Paranapanema rivers, was the frontier of the settlement during great part of the nineteenth century. The analysis from the parish and registry office in "Lençóes" (a city in Brazil) allowed us to mark out a family description in the frontier. Through this, we can see that the illegitimacy was low, smaller rather than in other areas that were used as a parameter, going against what people could expect from a frontier area. The baptisms used to take place in a large quantity at the end of the year (November and December), followed by the initial month, January. There weren't marked seasonal variations related to the baptisms, although October, February and March were the months with less occurrence. While Sunday was the preferred day by the parents for such a ceremony, concentrating approximately a third of them, Friday was a day to be avoided.

Keywords: Frontier; Birth; Legitimacy.

\section{Introdução}

Em outubro de 1876, o juiz de uma Comarca localizada no sertão paulista, ao relatar em correspondência às autoridades provinciais os problemas que se lhe apresentavam para manter a ordem na região sob sua jurisdição, traçava um panorama da extensa área ocidental da província entre os rios Tietê e Paranapanema:

É bastante attender que este termo é vastissimo em territorio, é o $1^{\circ}$ da Provincia; da sede do termo aos campos novos de José Theodoro, que são os ultimos moradores, tem uma extensão de cincoenta leguas mais ou menos, a fóra os terrenos desconhecidos que estendem pelas margens do rio Paranapanema até a sua foz no rio Paraná, e deste rio subindo acima até a embocadura no rio Tiete, e deste subindo até pouco acima do lugar denominado porto embocadura de Lençóes; occupando uma área de muitissimas leguas. A população não tem menos de vinte e

\footnotetext{
- Doutor em História pelo Programa de Pós-Graduação em História - Faculdade Ciências Humanas e Sociais - UNESP Univ. Estadual Paulista - Campus de Franca - Av. Eufrásia Monteiro Petráglia, 900, CEP: 14409-160, Franca, SP, Brasil. Este trabalho está relacionado a nossa tese de doutorado, defendida em 2008 sob orientação da Professora Doutora Dora Isabel Paiva da Costa. E-mail: edsonfer@1pnet.com.br
} 
tantas mil almas, cresce quase que diariamente com a emigração mineira para o lado do sertão ${ }^{1}$.

A Comarca em questão era a vila de Lençóes, pequeno núcleo urbano situado para além da serra de Botucatu e sob cuja jurisdição estava o vasto território que abrigava algumas freguesias para os lados do rio Paranapanema e inúmeros bairros rurais que gravitavam em torno do núcleo urbano -, além de sede de Comarca, centro administrativo, comercial e religioso.

Relatos da presença de índios e de criminosos que punham em perigo a vida dos esparsos moradores eram constantes desde as primeiras décadas do século XIX. Ainda no final do século, quando a fronteira do povoamento já se deslocava léguas a oeste, criando novos núcleos urbanos como Agudos e Bauru, a presença do perigo não passou despercebida aos olhos de ao menos uma moradora que havia se mudado para a região com a família para abrir uma fazenda de café (Fazenda do Engenho), em 1896, quando tinha 21 anos. Floriza Ferraz da Silveira Corrêa escreveu suas memórias em 1947. Sobre a época de sua chegada à região, diz que morava em uma casa:

[...] colocada na beira de uma estrada aberta e franca por onde transitavam n'aquella épocha, em demanda de outros sertões mais longincuos como o Salto Grande do Avanhandava, Espírito Santo do Turvo, Rio do Peixe, tranzitavam por ali rente de nossa casa, os célebres e temíveis fascinoras João Modesto e Dioguinho, que eram o terror de nossa zona. Elles faziam suas aparições de surpreza, e geralmente nas vendas ao lado das estradas, onde provocavam conflitos e mortes, obrigando a todo o mundo a andar armado de garrucha e de revolveres [...]. Viviam escondidos nas zonas entre Jahú, Campos Salles, Banharão, Barra Bonita e Pederneiras. Conheciam todas as estradas e desvios, andavam até por dentro das matas para não serem encontrados. Muitas vezes abuzavam porque n'aquelle tempo não havia policiamento (CORRÊA, 1947, p. 131-132).

Após relatar um problema com os colonos, Floriza compreende "os perigos que nos cercavam n'aquelle lugar isolado" receando "malfeitores e valentões que atravessavam pelo nosso terreiro e caminhos" (CORRÊA, 1947, p. 122-123).

\section{Primeiros povoadores}

Quando a Lei de 1850 regulamentou a aquisição de terras, muitos povoadores já tinham se apossado de um pedaço de chão na região centro-oeste paulista. Os primeiros povoadores vinham de regiões de povoamento mais antigo, eram lavradores e criadores oriundos de Sorocaba, São João do Rio Claro, Constituição, Mogi-Mirim, Belém do Descalvado, Itapetininga, Caconde, Casa Branca e de muitos municípios mineiros como Pouso Alegre, Cambui, Estiva, Borda da Mata, Cabo Verde e outros (FERNANDES, 2003, p. 8). José Teodoro de Sousa tornou-se uma figura quase lendária pelas andanças que realizou na região, fundando povoados, abrindo caminhos e trazendo povoadores de Pouso Alegre, onde morava antes de se aventurar pelo sertão paulista (MONBEIG, 1984, p. 133-135). 
Chegados ao local de destino (para muitos, apenas de passagem), estabelecidas suas moradas, estes primeiros povoadores eram seguidos por familiares ou amigos que engrossavam as fileiras dos que buscavam novas oportunidades em outras paragens. Os núcleos de povoamento salpicaram o vasto território da fronteira, ligados uns aos outros, ou aos núcleos urbanos já consolidados, por veredas ou incipientes caminhos, arremedos de estradas por onde circulavam pessoas, animais e mercadorias.

Aos poucos, formaram-se bairros rurais, sendo o bairro:

[...] a estrutura fundamental da sociabilidade caipira, consistindo no agrupamento de algumas ou muitas famílias, mais ou menos vinculadas pelo sentimento de localidade, pela convivência, pelas práticas de auxílio mútuo e pelas atividades lúdico-religiosas. As habitações podem estar próximas umas das outras, sugerindo por vezes um esboço de povoado ralo; e podem estar de tal modo afastadas que o observador muitas vezes não discerne, nas casas isoladas que topa a certos intervalos, a unidade que as congrega (CANDIDO, 1964, p. 44).

O bairro dos Lençóes surge nas primeiras décadas do século XIX. Em março de 1858, seus moradores pedem que seja elevado à Freguesia, o que efetivamente ocorre em 25 de abril daquele ano, apenas um mês após o pedido.

A freguesia dos Lençóes era ligada a Botucatu que, por sua vez, tornara-se vila, desmembrando-se de Itapetininga no ano de 1855. Elevado à freguesia, os moradores trataram de seguir em suas reivindicações. O próximo passo foi requerer a criação de uma subdelegacia. Consultado, o delegado da Vila de Itapetininga julgou desnecessária, o que fez com que o chefe da polícia interino informasse ao presidente da província que deixasse:

[...] por em quanto de crear-se a Subdelegacia proposta por José Pedroso do Amaral no Campo dos Lençoes, onde ainda não ha povoação nem capela propriamente ditas conforme se collige do officio do Subdelegado de Botucatú, o numero de seus habitantes é limitadissimo, sendo alem disso muito pobres e vivendo disseminados. ${ }^{2}$

Este povoamento ralo e disseminado, marcado por conflitos com os primitivos habitantes, marcou por algumas décadas a fronteira oeste. Martins caracteriza a fronteira como o lugar da alteridade, a um só tempo lugar de descoberta do outro e de desencontro:

[...] não só o desencontro e o conflito decorrentes das diferentes concepções de vida e visões de mundo de cada um desses grupos humanos. $\mathrm{O}$ desencontro na fronteira é o desencontro de temporalidades históricas, pois cada um desses grupos está situado diversamente no tempo da História. [...] A fronteira só deixa de existir quando o conflito desaparece, quando os tempos se fundem, quanto a alteridade original e mortal dá lugar à alteridade política, quando o outro se torna a parte antagônica do nós (MARTINS, 1997, p. 150-151).

Encontro dos que são diferentes entre si, cada um situado num tempo da História: índios e civilizados; grandes proprietários de terra e camponeses pobres. Assim foi o entorno do povoado de 
Lençóes praticamente até poucos momentos antes do fim da ordem monárquica, embora fosse, aos poucos, sendo construída a “ordem” institucional.

\section{Legitimidade e natalidade no sertão paulista}

Entre 1857 e 1889, foram efetuados registros do nascimento de 5.333 crianças livres na freguesia/vila de Lençóes. O vigário d. José Magnani, assinou o seguinte registro de batismo:

Aos trinta de novembro de mil oitocentos e oitenta e nove, nesta matriz, baptizei e puz os sanctos oleos a Pedro, filho natural de Firmina Maria de Jesus, nascido aos oito de julho deste anno: foram padrinhos Alfredo Lopes do Livramento e Maria do Espírito Santo, todos desta parochia. ${ }^{3}$

Seria mais um caso de ilegitimidade, não fosse pelo fato de que o menino Pedro também foi registrado no cartório da vila. Tal registro, porém, traz muito mais informações. Uma delas chama a atenção e diz muito da moral da época e do controle exercido pela igreja. Diz o texto:

Aos trinta dias do mez de novembro de mil oitocentos e oitenta e nove, nesta Villa
de Lençóes em meu cartorio perante mim escrivão compareceu Alfredo Lopes do
Livramento, e em prezença das testemunhas adiante nomeadas e assignadas,
declarou que na qualidade de padrinho declara o seguinte: que no dia quinze do
mez de junho do corrente anno, no bairro do Bom Jardim n'este município,
distante desta Vila duas leguas nasceu uma criança do sexo masculino o qual foi
posto o nome de Pedro, filho de Firmina Maria de Jesus, natural de Itapetininga,
solteira, occupada em serviços domésticos; deixando de declarar o nome do pai da
criança, por ser proibido; cuja criança tem por avos maternos João Rolim de Paula
e Maria do Espírito Santo; foi padrinho de baptismo da criança, elle declarante, e
madrinha Getrudes Antonia de Oliveira. E para constar lavrei este em que me
assigno com o declarante, fazendo a seu rogo por não saber escrever, Vicente
Lopes de Oliveira.

Estes dois registros permitem algumas reflexões. Os "pais incógnitos" descritos nos registros poderiam não ser, de fato, incógnitos, como alerta Fernando Torres-Londoño: “Tal afirmação não era verdadeira em todos os casos, já que o nome do pai podia ser conhecido, até mesmo pelo próprio pároco, mas por diversas razões não era registrado" (1999, p. 57). Como se vê, era este o caso.

Uma importante informação (o nome do pai) foi omitida no batismo. Ao que parece, o vigário seguia as instruções normativas das Constituições do Arcebispado da Bahia:

E quando o baptizado não for havido de legitimo matrimonio, tambem se declarará no mesmo assento do livro o nome de seus pais, se for cousa notoria, e sabida, e não houver escandalo; porém havendo escandalo em se declarar o nome do pai, só se declarará o nome da mãi, se tambem não houver escandalo, nem perigo de o haver. E havendo algum engeitado, que se haja de baptizar, a que se não saiba pai, ou mãi, tambem se fará no assento a dita declaração, e do lugar, e dia, e por quem foi achado (GALVÃO; NADALIN, 2000, p. 10). 
No entanto, Rafael Ribas Galvão e Sérgio Odilon Nadalin questionam se as Constituições eram lidas e executadas da mesma maneira por todos os padres, mesmo aqueles do interior, muitos deles com seus próprios filhos (GALVÃO; NADALIN, 2000, p. 2).

Alguns exemplos deste desconhecimento ou desrespeito dos padres às ordenações das Constituições são eloquentes. Há 32 batizados em Lençóes em que ambos os padrinhos eram homens e 1 em que havia duas madrinhas, contrariando as determinações superiores:

[...] mandamos que no bautismo não haja mais que hum só padrinho, huma só madrinha, que se não admittão juntamente dous padrinhos, duas madrinhas, os quaes padrinhos serão nomeados pelo pay, ou mây, ou pessoas, a cujo cargo estiver a criança [...] (PERARO, 2001, p. 181).

No dia 29 de abril de 1877, o capitão Delfino Alexandrino de Oliveira Machado e sua mulher D. Maria Januária da Rocha batizaram seu filho José, nascido no dia 20 daquele mês e ano. O menino teve duas madrinhas: d. Maria Isabel de Oliveira Machado e d. Ana Franco do Amaral César. O "capitão" e as "donas" antepostos aos nomes denunciam a "nobreza" dessa gente. Talvez por isso o padre Vito Januario Finamore tenha feito vistas grossas à flagrante desobediência, mas outros casos envolviam gente "comum".

Luis da Costa Raposo e sua mulher Francisca Marques batizaram Benedita, de 1 ano, no dia 21 de fevereiro de 1885. A menina teve dois padrinhos homens: João Gonçalves Ferreira e José Inácio de Sousa. O padre era Ambrosio Amâncio Coutinho. Como esses há dezenas de outros casos na paróquia de Lençóes.

Embora a omissão do nome do pai citado anteriormente tenha sido feita por um outro padre, d. José Magnani, estes exemplos mostram que as ordenações das Constituições nem sempre eram seguidas.

Casos de ilegitimidade como esse não eram comuns nessa parte do sertão paulista, ao contrário do que poderia parecer à primeira vista. A ilegitimidade de crianças livres era muito baixa em Lençóes, comparada a outras localidades, em que pese a situação de fronteira em que se caracterizava a região. Do total de 5.333 crianças registradas, 314 eram ilegítimas, representado $5,9 \%$ do total, bem abaixo da ilegitimidade de outras paróquias. Burmester (1974) calculou em 22,87\% a ilegitimidade na paróquia de Nossa Senhora da Luz, na segunda metade do século XVIII; Bacellar (2001) calculou a ilegitimidade de Sorocaba, entre o final do século XVII e as primeiras décadas do XIX, em 9,5\%; Ubatuba, estudada por Marcílio (2006) apresentava uma ilegitimidade de 17\% na população livre; a mesma autora (1973) encontrou alta ilegitimidade na paróquia da Sé: dos 21.681 batismos, 3468 eram crianças “expostas" e 5.032 filhos ilegítimos, resultando que $39,2 \%$ de crianças eram filhos bastardos. Teixeira (2004) estudou três períodos de Campinas; no total, encontrou uma baixa taxa de ilegítimos, 14,5\% (TABELA 1). 
Para Burmester, o alto índice de ilegitimidade na população livre da Paróquia de Nossa Senhora da Luz se explica pelas particularidades de uma região de trânsito: população aventureira, em parte dedicada ao comércio itinerante de gado, aliada à instabilidade favorecida pelas guerras sulinas e à extensão da paróquia $(1974$, p. 83). Já Bacellar não encontra explicações plausíveis para a baixa ilegitimidade de Sorocaba, comparativamente a outras paróquias. Segundo o autor, uma hipótese para tal índice, mas sem nada que comprove isso, seria o reforço da vigilância da Igreja sobre seu rebanho (2001, p. 190).

\begin{tabular}{lccc}
\multicolumn{4}{c}{ Tabela 1 - Sazonalidade comparada de batismos de crianças livres ilegítimas } \\
\hline Local/período & $\begin{array}{c}\text { Total de } \\
\text { batismos }\end{array}$ & $\begin{array}{c}\text { Ilegítimos e } \\
\text { expostos }\end{array}$ & $\%$ \\
N. S. da Luz / 1751-1800 (a) & 7.914 & 1.810 & 22,87 \\
Sorocaba / 1679-1830 (b) & 19.467 & 1.852 & 9,5 \\
Ubatuba / 1785-1830 (c) & 1.910 & $325^{*}$ & 17,0 \\
Campinas / 1774-1850 (d) & 15.075 & 2.145 & 14,5 \\
Paróquia da Sé / 1741-1845 (e) & 21.681 & 8.500 & 39,2 \\
Lençóes / 1859-1889** & 5.333 & 314 & 5,9 \\
\hline
\end{tabular}

* A autora não registra o número de casos, apenas a porcentagem, por isso este número pode ser uma unidade a mais ou a menos.

** Para esta tabela foram computados todos os nascidos, não apenas os batizados na igreja católica. Isto inclui os registrados apenas em cartório e os batizados na igreja presbiteriana.

FONTE: (a) Burmester, 1974; (b) Bacellar, 2001; (c) Marcílio, 2006; Teixeira, 2004, e ACB.

Marcílio, estudando a população caiçara do litoral norte paulista, explica a baixa ilegitimidade encontrada pela maior austeridade camponesa nas áreas rurais de economia de subsistência. Numa zona mais urbanizada, diz a autora, "a cidade de São Paulo na mesma época, encontramos um conjunto de 39\% entre naturais e expostos" (2006, p. 197). Teixeira observa que a alta legitimidade dos nascimentos de Campinas "demonstra uma marcante presença da Igreja nas paragens do interior paulista" (2004, p. 199). Faria (1988) compara “áreas de passagem” (como as regiões mineradoras, onde a ilegitimidade era maior), com as áreas agrícolas, onde:

[...] a movimentação é mais lenta do que em centros urbanos e mineradores - os ciclos de semeadura, limpeza e colheita são relativamente longos, mesmo para uma simples lavoura de subsistência, como a da mandioca (no mínimo a espera é de seis meses para a colheita). Montar um canavial era mais complicado (FARIA, 1998, p. 53).

Por isso, “mais do que uma 'austeridade do camponês', conclusão a que chegou Marcílio, os números espelham nitidamente uma realidade de comportamento familiar diferencial que está relacionada a diversas atividades econômicas e variada localização geográfica" (FARIA, 1998, p. 
57). A autora verificou que na Freguesia de São Salvador (RJ), região açucareira, 89,6\% das crianças livres eram legítimas, entre 1748 e 1798. Na Freguesia Nossa Senhora das Neves, também norte fluminense, legitimidade alcançava 90,8\% de livres, entre 1789 e 1813 (1998, p. 57).

Regiões "de passagem", “de fronteira" ou "de trânsito" têm sido caracterizadas por alta ilegitimidade. "Nos arraiais das minas, nos casarios de fronteira, nas vilas das áreas de trânsito, nesta geografia marcada pela mobilidade, constituíram-se famílias geradas pelos arranjos consensuais, por fora do casamento e atravessadas pela ilegitimidade", segundo Torres-Londoño (1999, p. 62).

Como área fronteiriça, Lençóes apresentava condições propícias a uma elevada taxa de ilegitimidade: povoamento recente, fronteira entre o mundo dito civilizado e os "terrenos desconhecidos", conflitos esporádicos com os índios. No entanto, sua taxa de ilegitimidade era extremamente baixa, 5,9\%. Eram apenas 314 ilegítimos e, entre eles, há o registro de apenas 3 crianças expostas. Dos 314 ilegítimos da Vila de Lençóes, 14 tinham pais conhecidos e nomeados no ato do batismo.

Embora uma região de fronteira, Lençóes não era uma região de trânsito, embora muitas famílias permanecessem por pouco tempo e novamente partissem. Não havia o problema de guerras contra o estrangeiro, nem ameaça de invasão e, consequentemente, não era necessária a constante mobilização de tropas. As escaramuças com os índios eram tentativas de expulsá-los para conquistar seus territórios, assim como os ataques indígenas eram tentativas de defesa deles. Ou seja, os temores de ameaças eram esporádicos e os conflitos temporários. Além disso, mobilizavam pequena parcela da população.

Ao que parece, a região correspondeu às expectativas de muitos que nela ingressaram, apostando num futuro promissor, de estabilidade financeira, o que refletiu numa estabilidade familiar. Claro que isso não se passou sem percalços e dificuldades de todo o tipo.

O "espírito aventureiro" daqueles que largaram sua terra natal e partiram para o sertão paulista acomodou-se quando encontraram um novo pedaço de chão e nele fizeram morada e família estável.

Se boa parte dos adventícios que povoou a região tinha um histórico familiar incerto, ao se fixar na terra, constituiu família regida por princípios religiosos, gerou filhos dentro do casamento e batizou-os na igreja. Talvez um "comportamento familiar diferencial", relacionado à atividade econômica e à localização geográfica, ou, uma "maior austeridade camponesa", também tenha produzido seus efeitos nesta sociedade afastada dos grandes centros urbanos e comerciais.

Se os naturais eram em pequeno número, os expostos eram ainda mais raros. Não havia "roda" em Lençóes, de modo que as poucas crianças enjeitadas das quais se têm registro foram deixadas à porta das casas ou simplesmente abandonadas no mato. Foi o que ocorreu numa sexta-feira do mês de 
novembro de 1889. Antonio Franco de Godoy caminhava próximo à margem direita do rio Lençóis quando se deparou - talvez alertado pelo choro - com uma criança recém-nascida, abandonada em meio à vegetação. Era por volta das seis e quinze da manhã. Antonio recolheu o menino e levou-o à Vila, distante daquele ponto um quarto de légua, entregando-o ao padre José Magnani. No mesmo dia a criança foi batizada com o nome de Moisés Etrusco - numa clara referência ao Moisés bíblico e ao episódio de seu recolhimento ${ }^{5}$. O padre soube depois que o menino havia nascido perto das nove horas da noite anterior. A mãe, Maria da Conceição, havia falecido. A sorte do menino, no entanto, durou pouco. Morreu poucos dias depois, "por causa da constituição viciosa de todo o seu organismo"6.

\section{Batismos}

A partir do momento em que a povoação de Lençóes passou a ser provida de padre (1861) até 1889 foram batizadas 5.051 crianças na igreja católica local. Os meses finais do ano concentravam o maior número de batismos (TABELA 2). Novembro e dezembro eram os meses preferidos pelos pais. Na sequência, janeiro também era um mês bastante procurado. Nos três meses seguintes, o número caia, para novamente elevar-se em maio e junho. Outubro era o mês de menor ocorrência desta cerimônia.

Tabela 2 - Movimento sazonal de batismos. Lençóes, 1861-1889

\begin{tabular}{l|cccc}
\hline $\begin{array}{l}\text { Mês de } \\
\text { batismo }\end{array}$ & $\begin{array}{c}\mathbf{N}^{\mathbf{0}} \mathbf{s} \\
\text { absolutos }\end{array}$ & Divisor & $\begin{array}{c}\mathbf{N}^{\mathbf{o}} \\
\text { diários }\end{array}$ & $\begin{array}{c}\mathbf{N}^{\mathbf{0}} \\
\text { proporcionais }\end{array}$ \\
\hline Janeiro & 446 & 31 & 14,39 & 104,1 \\
Fevereiro & 353 & 28,25 & 12,50 & 90,4 \\
Março & 419 & 31 & 13,52 & 97,8 \\
Abril & 376 & 30 & 12,53 & 90,7 \\
Maio & 432 & 31 & 13,94 & 100,8 \\
Junho & 419 & 30 & 13,97 & 101,1 \\
Julho & 423 & 31 & 13,65 & 98,7 \\
Agosto & 390 & 31 & 12,58 & 91,0 \\
Setembro & 398 & 30 & 13,27 & 96,0 \\
Outubro & 356 & 31 & 11,48 & 83,1 \\
Novembro & 498 & 30 & 16,60 & 120,1 \\
Dezembro & 541 & 31 & 17,45 & 126,2 \\
\hline Total & 5.051 & & 165,88 & 1.200 \\
\hline
\end{tabular}

FONTE: Tabela elaborada a partir dos registros de batismos do ACB.

Dentre os 5.051 registros, a maioria continha a data do nascimento da criança: $3.507(69,4 \%)$, muito embora tenham sido encontradas variações entre a data do nascimento registrado no cartório e aquela declarada no ato do batismo, reflexo do pouco apego da maioria da população - analfabeta 
- ao tempo medido pelo calendário. Além disso, é comum a indicação da idade da criança, medida em meses, às vezes anos, no lugar da data do nascimento. Há uma profusão de "um mês", “dous meses", "quatro meses", revelando a inabilidade com o tempo "oficial" desta gente, muito mais afeiçoada ao ritmo das estações do ano e ao calendário agrícola.

A Tabela 3 compara a sazonalidade dos batismos em várias localidades. Burmester não notou um movimento bem delineado para as cerimônias de batismo em seu estudo sobre a paróquia de Nossa Senhora da Luz, constatando apenas um maior número deles nos meses iniciais e finais do ano, e um declínio nos meses intermediários, principalmente no inverno, junho e julho (1974, p. 5860). Em Sorocaba, havia uma distribuição mais equilibrada de batismos durante o ano, com pequeno destaque para os meses de junho, novembro, julho, setembro e fevereiro (BACELLAR, 2001, p. 86).

Em Ubatuba, os meses de menor frequência de batizados de livres eram julho, março e dezembro, os dois últimos coincidentes com o período proibido. Para os demais meses do ano, havia uma distribuição relativamente equilibrada (MARCILIO, 2006, p. 233-234).

Em São Paulo, Marcílio anotou que "no decorrer da primeira metade do século XIX, o movimento sazonal é quase imperceptível; observamos uma queda nos meses de dezembro, e para os demais meses quase nenhuma flutuação" (2006, p. 154).

Teixeira encontrou para Campinas (1774-1850) uma maior quantidade de batismos nos meses de abril, maio, julho, setembro e novembro (2004, p. 62). Bacellar e Teixeira utilizam o mês de batismo para inferir a concepção, assim como fez Marcílio, que afirma que "os pais costumavam batizar seus filhos com poucos dias de idade" (2006, p. 229). Em uma amostra que esta autora fez, encontrou um tempo médio entre estes dois eventos de 20 dias apenas. Esta inferência para Lençóes é inviável, visto decorrer, na vila, um tempo maior entre o nascimento e o batismo. Afinal, ir à vila era uma atividade realizada apenas de tempos em tempos, em razão da distância e da dificuldade de locomoção de toda a família. No entanto, como a maioria dos nossos registros de batismo traz a data do nascimento, utilizaremos esta para inferir a concepção. 
Tabela 3 - Sazonalidade comparada de batismos na população livre

\begin{tabular}{l|ccccc}
\hline Meses & $\begin{array}{c}\text { Sorocaba / } \\
\text { 1683-1830 } \\
(\mathbf{a})\end{array}$ & $\begin{array}{c}\text { Nossa } \\
\text { Senhora da } \\
\text { Luz / 1751- } \\
\mathbf{1 8 0 0}(\mathbf{b})\end{array}$ & $\begin{array}{c}\text { Ubatuba / } \\
\mathbf{1 7 8 6 - 1 8 3 0} \\
(\mathbf{c})\end{array}$ & $\begin{array}{c}\text { Paróquia da } \\
\text { Sé / 1800- } \\
\mathbf{1 8 5 0}(\mathbf{d})\end{array}$ & $\begin{array}{c}\text { Lençóes / } \\
\mathbf{1 8 5 9 - 1 8 8 9}\end{array}$ \\
\hline Janeiro & 95 & 100,88 & 114 & 103 & \\
Fevereiro & 103 & 106,82 & 103 & 99 & 104,1 \\
Março & 88 & 90,62 & 79 & 99 & 90,4 \\
Abril & 94 & 92,00 & 101 & 101 & 97,8 \\
Maio & 98 & 92,42 & 99 & 104 & 100,7 \\
Junho & 109 & 89,06 & 113 & 100 & 101,1 \\
Julho & 107 & 87,82 & 66 & 101 & 98,7 \\
Agosto & 99 & 99,09 & 104 & 103 & 91,0 \\
Setembro & 105 & 104,88 & 115 & 101 & 96,0 \\
Outubro & 99 & 102,86 & 106 & 102 & 83,1 \\
Novembro & 108 & 118,50 & 116 & 97 & 120,1 \\
Dezembro & 94 & 115,00 & 84 & 90 & 126,2 \\
\hline
\end{tabular}

FONTE: (a) Bacellar, 2001; (b) Burmester, 1974; (c) Marcílio, 2006; (d) Marcílio, 1973 e ACB.

Há 3.476 crianças batizadas na igreja católica da vila de Lençóes, cujas datas de nascimento foram declaradas no ato. Embora tenham sido encontradas algumas discrepâncias entre a declaração do nascimento no cartório e no ato do batismo, pensamos que estes casos não alteram o quadro geral. Para os 1.633 restantes, os pais declararam a idade ao invés da data de nascimento. Fizeram isto de várias maneiras, sendo as mais comuns a idade em meses ou anos inteiros. Menos comum eram "meses e meio", e meses e dias ("um mês e cinco dias"). Alguns declaravam em meses mesmo quando a criança já passava de 1 ano ("dezoito meses de idade"). E, finalmente, alguns poucos batismos não apresentam nenhuma referência à idade.

Para a tabela 4, foram computados, além dos 3.476 batismos com data de nascimento declarada, aqueles com a idade em meses e dias, pois revelam um maior cuidado dos pais com relação ao dia do nascimento. Estes somam 36 casos. Em alguns deles, as crianças já têm uma idade "avançada": "7 meses e 7 dias", “4 meses e 23 dias", “6 meses e 15 dias", "8 meses e 11 dias". Portanto, temos um total de 3512 ocorrências.

Outubro, fevereiro e março eram os meses de menor ocorrência de concepções. Setembro, junho e novembro, por outro lado, eram os meses em que seu número era maior, embora, de modo geral, as concepções apresentassem pequenas variações durante o ano, diferentemente dos casamentos, como veremos adiante. 
Tabela 4 - Movimento sazonal de nascimentos e concepções. Lençóes, 1859-1889

\begin{tabular}{l|ccccc}
\hline $\begin{array}{l}\text { Mês de } \\
\text { nascimento }\end{array}$ & $\begin{array}{c}\text { Mês aprox. } \\
\text { da concepção }\end{array}$ & $\mathbf{N}^{\mathbf{o s}}$ absolutos & Divisor & $\mathbf{N}^{\mathbf{o s}}$ diários & $\begin{array}{c}\mathbf{N}^{\mathbf{o s}} \\
\text { proporcionais }\end{array}$ \\
\hline Janeiro & Abril & 309 & 31 & 9,97 & 103,67 \\
Fevereiro & Maio & 286 & 28,25 & 10,12 & 105,23 \\
Março & Junho & 333 & 31 & 10,74 & 111,68 \\
Abril & Julho & 285 & 30 & 9,50 & 98,79 \\
Maio & Agosto & 293 & 31 & 9,45 & 98,27 \\
Junho & Setembro & 324 & 30 & 10,80 & 112,30 \\
Julho & Outubro & 254 & 31 & 8,19 & 85,16 \\
Agosto & Novembro & 327 & 31 & 10,55 & 109,71 \\
Setembro & Dezembro & 285 & 30 & 9,50 & 98,79 \\
Outubro & Janeiro & 311 & 31 & 10,03 & 104,30 \\
Novembro & Fevereiro & 247 & 30 & 8,23 & 85,58 \\
Dezembro & Março & 258 & 31 & 8,32 & 86,52 \\
\hline Total & & 3.512 & & 115,4 & 1.200 \\
\hline
\end{tabular}

FONTE: Tabela elaborada a partir dos registros de batismos do ACB.

O menor número de concepções de março e fevereiro estava, provavelmente, ligado às interdições religiosas (lembrando que Advento e Páscoa eram móveis), diferentemente de julho, também de baixo índice de concepção. Talvez, nesse caso, o inverno tenha feito sua influência. De qualquer modo, as variações sazonais para as concepções em Lençóes não são muito acentuadas. Parece que a população lençoense comportava-se como os sorocabanos de Bacellar (TABELA 5), que comparou os meses de ocorrência de casamentos e concepções, observando que naqueles (cerimônias públicas e solenes) as interdições religiosas eram mais respeitadas, enquanto nestas, por serem realizadas no íntimo do lar, eram menos observadas (2001, p. 87-88).

Tabela 5 - Sazonalidade comparada de concepções na população livre em números proporcionais

\begin{tabular}{l|cc}
\hline Meses & $\begin{array}{c}\text { Sorocaba / 1683- } \\
\mathbf{1 8 3 0}(\mathbf{a})\end{array}$ & $\begin{array}{c}\text { Lençóes / 1859- } \\
\mathbf{1 8 8 9}\end{array}$ \\
\hline Janeiro & 99 & 104,30 \\
Fevereiro & 108 & 85,58 \\
Março & 94 & 86,52 \\
Abril & 95 & 103,67 \\
Maio & 103 & 105,23 \\
Junho & 88 & 111,68 \\
Julho & 94 & 98,79 \\
Agosto & 98 & 98,27 \\
Setembro & 109 & 112,30 \\
Outubro & 107 & 85,16 \\
Novembro & 99 & 109,71 \\
Dezembro & 105 & 98,79 \\
\hline
\end{tabular}

FONTE: (a) Bacellar, 2001 e ACB. 
As concepções em Sorocaba se distribuíam harmoniosamente ao longo do ano, com pequeno destaque para alguns meses: setembro, fevereiro, outubro e maio, sendo que este último provavelmente "estaria relacionado à Quaresma, quando os novos casais, constituídos em grande número em fevereiro, concebiam seu primeiro filho após a Páscoa". Junho era um mês de maior baixa, enquanto setembro apresentava um alto índice de concepções, diferente de Lençóes, onde estes dois meses apresentavam números parecidos. Segundo Bacellar, "em termos gerais, a sazonalidade das concepções em Sorocaba era influenciada tanto pelo calendário agrícola e pelas estações do ano quanto pelo calendário religioso" (2001, p. 86-87).

\section{O dia do Senhor}

Vários autores já chamaram a atenção para a importância do domingo nas sociedades camponesas. Marcílio diz que "a preferência pelo domingo ou pelo sábado marca um comportamento social típico das comunidades camponesas do Brasil arcaico” (2006, p. 219).

Antonio Candido, no clássico Os parceiros do Rio Bonito, diz que:

[...] a semana tem seu papel marcante no lazer, na recreação, nos contactos sociais, nas relações comerciais. O parceiro e o sitiante, nos períodos de menos trabalho, costumam dispor não apenas do domingo, mas do sábado, no todo ou em parte, para as idas ao povoado - a compras, transações, ou simples passeio. Nestes dias têm lugar as festas, nas capelas ou nas casas; as visitas de bairro a bairro; as recreações locais, como o jogo de malha; a caça e a pesca (1964, p. 96).

O domingo ${ }^{7}$ reinava absoluto quando se tratava de batizar os filhos em Lençóes (TABELA 6). Era o dia de ir à vila para a população que vivia espalhada pelos bairros rurais que formavam a vila. Um terço dos batismos era realizado neste dia.

Tabela 6 - Movimento semanal comparado de batismos

\begin{tabular}{|c|c|c|c|c|c|c|}
\hline \multirow[b]{2}{*}{ Dia } & \multicolumn{2}{|c|}{$\begin{array}{c}\text { Sorocaba / 1679-1830 } \\
\text { (a) }\end{array}$} & \multicolumn{2}{|c|}{$\begin{array}{c}\text { Campinas / 1774-1850 } \\
\text { (b) }\end{array}$} & \multicolumn{2}{|c|}{ Lençóes / 1859-1889 } \\
\hline & $\mathbf{N}$ & $\%$ & $\mathbf{N}$ & $\%$ & $\mathbf{N}^{\mathbf{0}}$ & $\%$ \\
\hline Segunda & 1.378 & 12,0 & 2.167 & 14,4 & 673 & 13,3 \\
\hline Terça & 1.059 & 9,3 & 1.616 & 10,8 & 456 & 9,0 \\
\hline Quarta & 994 & 8,7 & 1.463 & 9,7 & 440 & 8,7 \\
\hline Quinta & 1.098 & 9,6 & 1.449 & 9,6 & 429 & 8,5 \\
\hline Sexta & 896 & 7,8 & 1.242 & 8,3 & 372 & 7,4 \\
\hline Sábado & 1.204 & 10,6 & 1.882 & 12,5 & 926 & 18,3 \\
\hline Domingo & 4.809 & 42,0 & 5.210 & 34,7 & 1755 & 34,8 \\
\hline Total & 11.438 & 100 & 15.029 & 100 & 5.051 & 100 \\
\hline
\end{tabular}

FONTE: (a) Bacellar, 2001; (b) Teixeira, 2004, ACB. 
Aos sábados e segundas também era alto o número de crianças batizadas, comportamento comum às outras localidades: Teixeira e Bacellar também notaram a preponderância destes mesmos dias para Campinas e Sorocaba. O dia a ser evitado, tanto num como noutros casos, era a sexta. A diferença entre Lençóes e as duas outras localidades refere-se ao segundo dia de preferência: segunda-feira para estas localidades; sábado, para aquela.

\section{Conclusão}

Como área fronteiriça, Lençóes apresentava condições propícias a uma elevada taxa de ilegitimidade, que já foi vista como uma característica da família brasileira de outrora. Em que pesem as condições adversas à estabilidade dos arranjos familiares, próprias de uma área em início de povoamento, sua taxa de ilegitimidade era extremamente baixa, 5,9\%, talvez um sinal de que a região tenha correspondido às expectativas dos adventícios, o que teria permitido certa estabilidade familiar e maior respeito aos princípios religiosos.

Um comportamento da família na fronteira que destoa se comparado a estudos sobre outras áreas refere-se à predominância de dezembro para batismos. Além deste mês, novembro e janeiro também eram meses de bastante ocorrência deste tipo de cerimônia. Quanto ao dia preferido, domingo reinava absoluto, comportamento comum a outras localidades espalhadas pelo Brasil. Com relação à concepção, as variações sazonais para as concepções em Lençóes não são muito acentuadas. Parece que a população lençoense comportava-se como os sorocabanos estudados por Bacellar. Ele observou que nos casamentos, cerimônias públicas e solenes, as interdições religiosas eram mais respeitadas do que nas íntimas concepções.

As famílias formadas nas condições que a fronteira permitia apresentavam alguns padrões e estratégias coincidentes com outras áreas, em outros tempos e lugares. Distintos comportamentos, no entanto, revelam diferenças significativas que não podem ser explicadas recorrendo às análises já consagradas em estudos do nosso passado.

\section{Referências Bibliográficas}

BACELLAR, C. A. P. Viver e sobreviver em uma vila colonial: Sorocaba, séculos XVIII e XIX. São Paulo: Annablume : FAPESP, 2001.

BURMESTER, A.M.O. A população de Curitiba no século XVIII segundo os registros paroquiais, 1751-1800. 1974. 108f. Dissertação (Mestrado em História), Universidade Federal do Paraná, 1974.

CANDIDO, A. Os parceiros do Rio Bonito: estudo sobre o caipira paulista e a transformação dos seus meios de vida. Rio de Janeiro: José Olympio, 1964. 
Constituições Primeiras do Arcebispado da Bahia, 1707, Livro I, Título XVIII, § 64, p. 28-29 apud PERARO, M.A. Bastardos do Império: família e sociedade no Mato Grosso no século XIX. São Paulo: Contexto, 2001.

Constituições Primeiras, Título XX, 1853: 30 apud GALVÃO, Rafael Ribas; NADALIN, Sergio Odilon. Bastardia e ilegitimidade: murmúrios dos testemunhos paroquiais durante os séculos XVIII e XIX (nota prévia). In: ENCONTRO NACIONAL DE ESTUDOS POPULACIONAIS, 12., 2000, Caxambu. Anais.... Caxambu: ABEP, 2000. v. 1.

CORRÊA, Floriza Ferraz da Silveira. Manuscrito inédito, cedido pela família, 1947.

FARIA, S. C. A colônia em movimento: fortuna e família no cotidiano colonial. Rio de Janeiro: Nova Fronteira, 1998.

FERNANDES, E. Escravidão na fronteira: um estudo da escravidão negra numa boca de sertão paulista. Lençóes, 1860-1888. 2003. Dissertação (Mestrado em Economia) - Programa de PósGraduação em Economia, Universidade Estadual Paulista "Júlio de Mesquita Filho", Araraquara, 2003.

MARCÍLIO, M. L. Caiçara: terra e população: estudo de demografia histórica e da história social de Ubatuba. 2. ed. São Paulo: Ed. USP, 2006.

A cidade de São Paulo: povoamento e população, 1750-1850, com base nos registros paroquiais e nos recenseamentos antigos. São Paulo: Pioneira: Ed. USP, 1973.

MARTINS, J.S. Fronteira: a degradação do outro nos confins do humano. São Paulo: Hucitec, 1997.

MONBEIG, P. Pioneiros e fazendeiros de São Paulo. São Paulo: Hucitec: Polis, 1984.

TEIXEIRA, P. E. A formação das famílias livres e o processo migratório: Campinas, 1774-1850. 2004. 296 f. Tese (Doutorado em História) - Programa de Pós-Graduação em História Econômica, Universidade de São Paulo, São Paulo, 2004.

TORRES-LONDOÑO, F. A outra família: concubinato, igreja e escândalo na colônia. São Paulo: Edições Loyola, 1999.

\section{Fontes}

Acervo Particular. Manuscrito de Floriza Ferraz da Silveira Corrêa. Inédito.

AESP - Arquivo do Estado de São Paulo

ACB - Arquivo da Cúria de Botucatu, SP

CRCA - Cartório de Registro Civil e Anexos de Lençóis Paulista

\section{NOTAS}

${ }^{1}$ Caixa 296, Ordem 1091, Ofícios diversos 1849-1891, Pasta 2, AESP.

${ }^{2}$ Caixa 296, Ordem 1091, Ofícios diversos 1849-1891, Pasta 1, AESP.

${ }^{3}$ Livro de Batismos 80, registro 394, 30 de novembro de 1889, ACB

${ }^{4}$ Livro de Nascimentos A1, registro 122, 30 de novembro de 1889, CRCA. (grifo nosso).

${ }^{5}$ Livro de Batismos 80, registro 380, 3 de novembro de 1889, ACB. 
${ }^{6}$ Livro de Óbitos 40, registro 112, 19 de novembro de 1889, ACB.

${ }^{7}$ Para a determinação do dia da semana foi utilizado o Calendário Perpétuo, visto que os registros não traziam tal informação.

Artigo recebido em 04/2010. Aprovado em 09/2010. 